\title{
NOTES ON SANNINA UROCERIFORMIS.
}

BY GLeNN W. HERRICK, AGRicUlturat COLlege, Miss.

During the spring of 1906 one of my correspondents sent me two battered and broken female moths of the family Sesiida from Ocean Springs, Miss. Supposing them to be from the Peach tree, and from their battered condition not being able to make out their markings distinctly, I called them $S$. exitiosa. Having occasion to visit the fruit farm of this correspondent this spring, I was surprised to find that the moths in question were collected from pupæ on wild Persimmon trees. It was therefore with a good deal of interest that I began a careful examination of the few wild Persimmon trees on his place, and other trees of the same kind in the vicinity. This was on May 4. We were much disappointed at first in our search, because we found only empty pupa-cases, from which the adults had already and very lately flown. We found over twenty empty cases on about a dozen trees, from one inch to two inches in diameter. We were finally rewarded, however, by finding three or four fresh pupæ in some trees which had their bases heaped about with dead straw. From these we went to adjoining fields, where there were a great many small Persimmons, from one-half an inch to an inch and a half in diameter, that had been allowed to grow up in abandoned waste fields. Here among the deep grass around the bases of the trees we found twenty-odd living pupre.

The larve of this moth bore into the solid wood of the taproot and stem of the Persimmon. I was unable to trace their burrows farther than eight or ten inches below the surface, but this was probably due to the small size of the trees, for Dr. Riley says they bore from i 6 to I 8 inches below the ground.

In most of the trees examined, one borer only was present, and in this case it usually bored directly up the centre of the tree (Plate 8, a and d). In larger trees two or more borers might be present, depending upon the size of the trees. In such instances they divide the space between them (Plate 8, b).

When ready to pupate, the larva extends its burrow two to four inches above the ground, turns it outward, cutting through the bark, and constructs a large cocoon on the side of the tree, usually at an angle of about $45^{\circ}$ to the stem (Plate $8, \mathrm{c}$ ). The cocoons are dark in colour, and vary all the way from one inch to two and a half inches in length. The cocoon at $c$ is two and one-half inches long.

August, I9o7 
The pupæ possess the power of movement to an astonishing degree, and when disturbed back quickly downward into their burrows. This is so characteristic of them that we were obliged to approach a tree rather carefully, and quietly tear away the grass and debris around the base without disturbing the cocoon if we wanted to be sure of our specimen. I lost some entirely, and cut others in two just as they were backing from their cocoon into the burrow in the tree. Again, so many pupæ backed out of their cocoons after the latter were removed that they dried out and failed to transform.

The records of the appearance of the moths are as follows:

Many empty pupa-cases found May 4

One male May 8.

One female May 8.

One male May 9.

One female May io.

One female May i I.

One male May i 3 .

Some are yet to transform (May ı 8).

These borers must injure the native Persimmon much more than a Peach-tree borer does a Peach tree, although I found no borers in large trees. They seemed to be confied to the young and small trees.

It is also an interesting fact that we were unable to find a single borer in the cultivated Japanese Persimmon trees standing in close proximity to the wild infested trees.

MOSQUITO NOTES.-No. 5.-Continued.

BY C. S. LUDLOW, M. SC.

Laboratory of the Office of the Surgeon-General, U. S. Army, Washington, D. C.

Among the mosquitoes sent in during the collecting period of I 906 in the U. S., was an Anophelina which has caused me some perplexity. The general colouring at once suggested one of the sinensis group, and it occurred to me that some joke had been perpetrated, so I wrote the collector, asking if it were possible that any Philippine mosquitoes had gotten in with these. He, however, said it was quite impossible, as he had no P. I. mosquitoes with him when this collection was made. No specimens resembling this had previously been received from the U. S., so that I was somewhat reluctant at first to accept it, but as closer study shows it August, 190; 